\title{
How Long Should An Individual At Full Retirement Age Delay Receiving Social Security Benefits?
}

Fred Hebein, USA

\begin{abstract}
An important topic for many individuals approaching 66 in 2011 is whether to start social security benefits at full retirement age (FRA) or to delay the benefits in order to gain greater payouts in the future. In 2009, the bonus for delaying the start of benefits rose to about $8 \%$ per year. By delaying benefits for four years (to age 70), it is possible to increase benefits by 38 to 55 percent per month for the remainder of the retiree's life. In addition to the higher monthly benefits from delaying start of benefits, there are also substantial benefits for high income retirees in relocating to lower tax states. Also, given that the remaining age to death for most retirees at FRA is clearly finite, one would expect to see some value in discounting future earnings.
\end{abstract}

Our paper evaluates accumulated benefits over a 25 year time horizon to assess retirement decisions post FRA. We consider three examples of accumulated benefits: (1) constant dollar accumulated benefits without discount or taxes; (2) alternative rates of discount of the future stream of earnings without income taxes; and (3) discounted after tax benefits. Each scenario is evaluated to assess whether delaying social security benefits past FRA is a profitable idea. Based upon our analysis, any discount rate in excess of $5 \%$ of the available after-tax returns provides no breakeven age within expected life ages. That is, at high discount rates, it is always better to start benefits at FRA or with only short delay once FRA is reached, if the individual wishes to maximize accumulated benefits over the expected life.

At discount rates of less than 3\%, the accumulated benefits may be increased within the expected life span by delaying the start of benefits. If no discount rate is applied, accumulated benefits are maximized by delayed start since all breakeven ages occur within life expectancy. In addition, we find that the negative impact of taxes on accumulated benefits can be as large as a discount rate of $3 \%$ on accumulated benefits. For high income retirees, a strategy of (1) relocating to lower tax states and (2) delaying the start of benefits can provide substantial increases to accumulated benefits. Finally, we note that the retirement decision is not entirely financial, but that many factors including family, spouse, work climate, health, expected life span, and fear of running out of money lead individuals into making decisions that may not optimize the present value of future benefits.

\section{BACKGROUND}

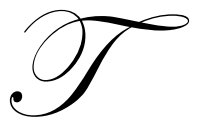

he social security insurance program is one of the most popular and widely used government programs. Social security provides more than 50 percent of total income for almost two-thirds of beneficiaries over 65. For one-third of the beneficiaries, social security accounts for 90 percent of total income. For twenty one percent of the beneficiaries, social security provides $100 \%$ of total income (Fisher, 2007; SSA, 2004). That is, for the least fortunate one-fifth, social security is their only source of income (Diamond and Orszag, 2004). 
On reaching 62 years of age, qualified individuals can begin receiving social security benefits. However, benefits at 62 years of age are reduced to $75 \%$ of the beneficiary's Primary Insurance Amount (PIA). The PIA is calculated by (1) determining the Average Indexed Monthly Earnings (AIME) and then by (2) applying the PIA formula. To calculate AIME, the individual's taxable income from the highest earning 35 years of work is multiplied by an index number for each given year. The index number adjusts taxable income for inflation over a retiree's life time horizon of up to 35 years.

Once AIME is determined, PIA is calculated from a progressive formula, which weights the lower income amounts in the AIME heavier, thereby favoring low income wage earners. In 2009, The PIA formula took $90 \%$ of the first $\$ 744$ of AIME, $32 \%$ of the next $\$ 3739$ of AIME, and then $15 \%$ of AIME in excess of $\$ 4483$. Examples of AIME and PIA calculations are shown on the social security website.

As noted above, retirees at 62 years of age receive $75 \%$ of PIA. To gain $100 \%$ of PIA, the retiree must be at Full Retirement Age (FRA). For individuals born during the years 1945-1954, the FRA is 66 years of age. That is, to gain $100 \%$ of PIA, individuals born in those years must wait until 66 years of age to begin benefit payments.

In addition to the lower proportion of PIA received by beneficiaries not yet at FRA, there is also an annual earnings limit ( $\$ 14,160$ in 2009). If an individual's earnings exceed $\$ 14,160, \$ 1$ of benefits is withheld for every $\$ 2$ earned above $\$ 14,160$. The earnings limit can be severe. If an individual's annual benefit is $\$ 12,000$ per year, the individual will lose all social security benefits by earning $\$ 38,160$ : $(\$ 38,160-\$ 14,160=\$ 24,000 ; \$ 24,000 \times .5=$ $\$ 12,000)$.

Furthermore, by beginning benefits too early, the retiree forgoes the potential increases in AIME and PIA, which would occur as past lower wages at the beginning of the work history are replaced by current higher wages in the more skilled later years. Clearly, individuals who wish to take social security benefits before FRA are significantly reducing monthly benefits relative to only four years hence.

In fact, some analysts (Muksian,2011)believe that delaying benefits until FRA is virtually mandated because of (1) the substantial increase in percent of benefits paid (75\% at age 62 to $100 \%$ at age 66 ); (2) the additional contributions from continuing to work; and (3) the taxation of social security benefits received prior to FRA. Taking benefits before FRA is recommended only for individuals in distress because of illness or disability, job loss (with little prospect for future employment), or overwhelming family demands (caregiving to relatives).

\section{THE QUESTION FOR RETIREES}

Given that the correct decision for almost all individuals is to wait until FRA is reached before starting benefits, the dilemma of when to start receiving benefits is shifted to the period after FRA and before age 70, when beginning receipt of benefits is required. The decision post FRA is difficult because of our inability to accurately estimate individual longevity and long-term health, and because of the rather dramatic increase in benefits awarded for delay. Delayed benefits receive a double compounding from (1) cost-of-living adjustments (COLA) and (2) from the $2 / 3 \%$ per month increase (usually reported as $8 \%$ per annum)in benefits awarded for delaying receipt of benefits. For example, a 3\% annual COLA increase plus an $8 \%$ delay adjustment yields a $54 \%$ increase in benefits over a four year period $[(1.03 * * 4) \mathrm{X}(1.0066667 * * 48)=1.548]$.

Furthermore, the structure of social security benefits themselves contributes to the difficulty of the decision. Theoretical economic models of the social security system, designed primarily for policy makers (Crawford and Lilien, 1981) note that because of uncertain lifetimes, social security tends to create an "income" and "substitution" effect. The income effect tends to encourage early retirement, because workers see a continuation of income without working, and the substitution effect tends to delay retirement because the benefits of social security can only be fully realized by working longer.

Given that most individuals will make a post FRA decision, Muksian (2011) and Fahlund (2011) use the accumulation of actual benefits and the accumulation of post-tax invested benefits at various rates of return to assess break even ages. The breakeven age occurs when the accumulated benefits from delayed start equal the accumulated benefits from starting at FRA. For invested benefits, the greater the after-tax rate of return, the greater 
the break even age. Above $9 \%$ per annum, the breakeven age is 90 or greater which indicates that an immediate start of benefits at FRA is optimal. For simple benefit accumulation (not adjusted for taxes or investment return), the break even age usually occurs in the late 70's or early 80 's, depending upon how long the start of benefits is delayed.

We should note here that the official social security web site (www.socialsecurity.gov.) also uses accumulation without adjustment for taxes or rate of return. In general, if a post-tax investment return of $5 \%$ can be achieved (Fahlund, 2011), the retiree is better off taking their social security benefits at FRA. However, the retirement decision is also complicated by non-financial factors which can influence the decision to delay benefits, such as the preferences of a spouse or the climate at work (Henkens and Solinge, 2002).

Given the complexity of the retirement decision and the number of factors involved, the emphasis of this paper is to provide accessible information to individuals facing retirement decisions. The paper presents analysis of accumulated benefits for scenarios of (1) constant dollar accumulated benefits without future discount or taxes; (2) constant dollar accumulated benefits with alternative rates of future discount without income taxes; and (3) constant dollar after tax accumulated benefits with alternative rates of future discount.

\section{ANALYSIS AND TABLES}

In the following tables, the analysis is summarized for various alternative rates of inflation, Cost-of-Living Adjustment (COLA), discount rates to present value, and low and high income tax rates. The tables are presented in terms of index numbers, where 1.0 is the annual PIA at FRA. Since the level of benefits can be different for each beneficiary, we employ an index to avoid the problem of choosing enough monthly dollar amounts to represent a wide range of individual beneficiaries. Prospective users of this analysis can simply take their PIA and multiple it by the numbers in each cell to get their numerical amount.

Table 1: Cumulative Constant Unit Benefits By Age By Starting Year Assumptions: Inflation Rate $=$ COLA $=0$; Discount Rate $=0$

\begin{tabular}{|c|c|c|c|c|c|c|}
\hline Year & Age & $\begin{array}{c}\text { FRA } \\
\text { Age } 66\end{array}$ & $\begin{array}{c}\text { Delay } 1 \text { Year } \\
\text { Age } 67\end{array}$ & $\begin{array}{c}\text { Delay } 2 \text { Years } \\
\text { Age } 68\end{array}$ & $\begin{array}{c}\text { Delay } 3 \text { Years } \\
\text { Age } 69\end{array}$ & $\begin{array}{c}\text { Delay } 4 \text { Years } \\
\text { Age } 70\end{array}$ \\
\hline 2011 & 66 & 1.0000 & 0.0000 & 0.0000 & 0.0000 & 0.0000 \\
\hline 2012 & 67 & 2.0000 & 1.0830 & 0.0000 & 0.0000 & 0.0000 \\
\hline 2013 & 68 & 3.0000 & 2.1660 & 1.1729 & 0.0000 & 0.0000 \\
\hline 2014 & 69 & 4.0000 & 3.2490 & 2.3458 & 1.2702 & 0.0000 \\
\hline 2015 & 70 & 5.0000 & 4.3320 & 3.5187 & 2.5405 & 1.3757 \\
\hline 2016 & 71 & 6.0000 & 5.4150 & 4.6916 & 3.8107 & 2.7513 \\
\hline 2017 & 72 & 7.0000 & 6.4980 & 5.8644 & 5.0810 & 4.1270 \\
\hline 2018 & 73 & 8.0000 & 7.5810 & 7.0373 & 6.3512 & 5.5027 \\
\hline 2019 & 74 & 9.0000 & 8.6640 & 8.2102 & 7.6214 & 6.8783 \\
\hline 2020 & 75 & 10.0000 & 9.7470 & 9.3831 & 8.8917 & 8.2540 \\
\hline 2021 & 76 & 11.0000 & 10.8300 & 10.5560 & 10.1619 & 9.6297 \\
\hline 2022 & 77 & 12.0000 & 11.9130 & 11.7289 & 11.4321 & 11.0053 \\
\hline 2023 & 78 & 13.0000 & 12.9960 & 12.9018 & 12.7024 & 12.3810 \\
\hline 2024 & 79 & 14.0000 & 14.0790 & 14.0747 & 13.9726 & 13.7567 \\
\hline 2025 & 80 & 15.0000 & 15.1620 & 15.2476 & 15.2429 & 15.1324 \\
\hline 2026 & 81 & 16.0000 & 16.2450 & 16.4204 & 16.5131 & 16.5080 \\
\hline 2027 & 82 & 17.0000 & 17.3280 & 17.5933 & 17.7833 & 17.8837 \\
\hline 2028 & 83 & 18.0000 & 18.4110 & 18.7662 & 19.0536 & 19.2594 \\
\hline 2029 & 84 & 19.0000 & 19.4940 & 19.9391 & 20.3238 & 20.6350 \\
\hline 2030 & 85 & 20.0000 & 20.5770 & 21.1120 & 21.5941 & 22.0107 \\
\hline 2031 & 86 & 21.0000 & 21.6600 & 22.2849 & 22.8643 & 23.3864 \\
\hline 2032 & 87 & 22.0000 & 22.7430 & 23.4578 & 24.1345 & 24.7620 \\
\hline 2033 & 88 & 23.0000 & 23.8260 & 24.6307 & 25.4048 & 26.1377 \\
\hline 2034 & 90 & 24.0000 & 24.9090 & 25.8036 & 26.6750 & 27.5134 \\
\hline 2035 & 91 & 25.0000 & 25.9920 & 26.9764 & 27.9452 & 28.8890 \\
\hline
\end{tabular}


Turning to Table 1, note that Table 1 has zero inflation, no COLA, no income taxes, and no discount rate. The table shows the accumulated amount of benefits by age over a twenty-five year period. The FRA column assumes that benefits begin at 66 years of age. The column with heading of DELAY 1 YEAR assumes benefits begin at 67 years of age. Similarly, DELAY 2 YEARS starts at 68 years of age, DELAY 3 YEARS at 69, and DELAY 4 YEARS at 70. The cells with heavy borders note the breakeven ages for delaying benefits. The breakeven age is when accumulated benefits for a later starting age equal or exceed an earlier starting age.

For example, the breakeven age for starting at 67 years of age versus 66 occurs at 79 years of age when accumulated benefits for DELAY 1 YEAR equals 14.0790, which is greater than 14.0000 for 66 years of age (FRA) start. The breakeven age for DELAY 2 YEARS occurs at 80 years of age, when accumulated benefits of 15.2476 exceed those of DELAY 1 YEAR (15.1620). In Table 1, each additional year of delay, beginning at 79 years of age, adds a year to breakeven age until the accumulated benefits of DELAY 4 (17.8837) exceed those of DELAY 3 (17.7833).

The results in Table 1 indicate that breakeven ages for delaying benefits all occur within the 84 years expected life span of a male reaching 66 years of age. The accumulated benefits for delaying the start of social security pays off in the sense of gaining greater lifetime income. With a discount rate of zero, benefits in the future are of the same value as benefits today. The results shown in Table 1 suggest that retirees would optimize future income by delaying the start of social security benefits. The results in Table 1 are similar to those reported by Muskian (2011), Furlung (2011), and are similar to the results shown on the social security website.

\section{COLA and Inflation}

After benefits begin, beneficiaries are protected against inflation by Cost-of-Living Adjustments (COLA). The inflation adjustment is based upon the CPI-W, the Consumer Price Index for Urban and Clerical Workers. The COLA formula computes the annual percent difference between the average of CPI-W in the third quarter of the latest year with the third quarter average of CPI-W from the most recent year with a change in COLA. For example, when calculating the 2010 COLA, the third quarter average is compared to the 2008 third quarter average because no change in COLA occurred in 2009. No change in COLA occurs when the COLA formula computes a decrease in COLA; when calculating benefits for such a year, no decrease in benefits is applied.

For the years where COLA increase, the calculated percent increase is rounded to the nearest tenth and becomes the COLA applied on January 1, in the succeeding year. While there is some discussion on the composition and biases within the CPI-W compared to actual expenditures by beneficiaries (Hobijn and Lagakos, 2003; Duggan and Gillingham, 1999) the fundamental purpose of COLA is to maintain benefits at the same constant dollar amount.

Therefore, the results in Table 1 are the same for different rates for inflation and COLA, because the benefit amount is multiplied and divided by the same coefficient. For example, a 3\% inflation rate assumed over the remaining life of the beneficiary would lead to a 3\% adjustment in COLA and the benefits in real dollar amounts would be the same as shown in Table 1. Given that the goal of COLA is to maintain purchasing power of beneficiaries, for the purposes of this paper, we can use Table 1 as our base calculation in constant dollars for retiree benefits for the forecast period.

\section{Discount to Present Value and Benefits Adjusted for Taxes}

As analysis from Table 1 has shown, beneficiaries can expect to receive greater accumulated payments by age 82 even after delaying benefits for up to four years. The unit incomes shown in Table 1 can be viewed as units of constant dollars since they are adjusted for inflation through COLA. However, the accumulated earnings are not adjusted for time preference: That is, beneficiaries, because of finite and uncertain life times, may have greater preferences for current benefits relative to future benefits. Table 2 introduces discounting of future benefits by a factor of 1.03 , or a $3 \%$ discount rate. At a $3 \%$ discount rate, benefits in 23.5 years have only half of the value of current period benefits $\left(1.03^{\wedge} 23.5=2.003\right)$. In other words, current retirees at FRA (66 years of age) would value benefits at 89.5 years of age at only half the amount if those benefits were received today. 
Table 2: Cumulative Constant Unit Benefits By Age By Starting Year Assumptions: Inflation Rate $=$ COLA; Discount Rate $=3 \%$

\begin{tabular}{|c|c|c|c|c|c|c|}
\hline Year & Age & FRA & Delay 1 Year & Delay 2 Years & Delay 3 Years & Delay 4 Years \\
\hline 2012 & 66 & 1.0000 & 0.0000 & 0.0000 & 0.0000 & 0.0000 \\
\hline 2013 & 67 & 1.9709 & 1.0515 & 0.0000 & 0.0000 & 0.0000 \\
\hline 2014 & 68 & 2.9135 & 2.0723 & 1.1056 & 0.0000 & 0.0000 \\
\hline 2015 & 69 & 3.8286 & 3.0634 & 2.1789 & 1.1624 & 0.0000 \\
\hline 2016 & 70 & 4.7171 & 4.0256 & 3.2210 & 2.2910 & 1.2223 \\
\hline 2017 & 71 & 5.5797 & 4.9598 & 4.2328 & 3.3868 & 2.4089 \\
\hline 2018 & 72 & 6.4172 & 5.8668 & 5.2150 & 4.4506 & 3.5610 \\
\hline 2019 & 73 & 7.2303 & 6.7474 & 6.1687 & 5.4834 & 4.6796 \\
\hline 2020 & 74 & 8.0197 & 7.6023 & 7.0946 & 6.4861 & 5.7655 \\
\hline 2021 & 75 & 8.7861 & 8.4324 & 7.9935 & 7.4597 & 6.8199 \\
\hline 2022 & 76 & 9.5302 & 9.2382 & 8.8663 & 8.4048 & 7.8435 \\
\hline 2023 & 77 & 10.2526 & 10.0206 & 9.7136 & 9.3225 & 8.8373 \\
\hline 2024 & 78 & 10.9540 & 10.7802 & 10.5362 & 10.2134 & 9.8022 \\
\hline 2025 & 79 & 11.6350 & 11.5177 & 11.3349 & 11.0784 & 10.7389 \\
\hline 2026 & 80 & 12.2961 & 12.2336 & 12.1103 & 11.9181 & 11.6484 \\
\hline 2027 & 81 & 12.9379 & 12.9288 & 12.8631 & 12.7335 & 12.5314 \\
\hline 2028 & 82 & 13.5611 & 13.6037 & 13.5940 & 13.5250 & 13.3887 \\
\hline 2029 & 83 & 14.1661 & 14.2589 & 14.3037 & 14.2935 & 14.2210 \\
\hline 2030 & 84 & 14.7535 & 14.8951 & 14.9926 & 15.0397 & 15.0290 \\
\hline 2031 & 85 & 15.3238 & 15.5127 & 15.6615 & 15.7641 & 15.8136 \\
\hline 2032 & 86 & 15.8775 & 16.1123 & 16.3109 & 16.4674 & 16.5752 \\
\hline 2033 & 87 & 16.4150 & 16.6945 & 16.9414 & 17.1502 & 17.3147 \\
\hline 2034 & 88 & 16.9369 & 17.2597 & 17.5535 & 17.8131 & 18.0327 \\
\hline \multirow[t]{2}{*}{2035} & 90 & 17.4436 & 17.8084 & 18.1478 & 18.4567 & 18.7297 \\
\hline & 91 & 17.9355 & 18.3412 & 18.7248 & 19.0816 & 19.4065 \\
\hline
\end{tabular}

Looking at Table 2, which shows inflation adjusted constant units with a 1.03 percent discount rate, the breakeven years are 82 to 85 with 1 to 4 years of delay respectively. The preference for current benefits over future benefits delays breakeven by three years (compared to Table 1) to 85 years of age for the choice of delay of four years. The $85^{\text {th }}$ year is one year beyond the expected life span of men who survive to 66 years of age. If the individual choosing the 4 year delay option is in good health with high expectations of reaching or exceeding 85 years of age, the delay of four years is still an optimizing choice. From Table 2 we can conclude that even modest rates of discounting extend the break even age for each year of delay by three years compared to Table 1 . However, even with a $3 \%$ discount rate, all of the break even ages, except delay 4, occur within the expected life span of 84 years for males reaching 66 years of age today.

What occurs if we increase the discount rate to 5 percent? At a $5 \%$ discount rate, the value of benefits declines by $50 \%$ in 14.21 years $\left(1.05^{\wedge} 14.21=2.0003\right)$. In other words, a retiree starting benefits at 66 values benefits received at 80 at about half of current value. Looking at Table 3, the break even ages for delay 1 year to delay 4 years span from 85 years of age to 88 years of age. Clearly, this suggests that retirees with high strong preference for current earnings should not delay receiving benefits. All of the breakeven ages exceed expected life span including start at FRA. That is, at 5 percent discount rates, the optimum starting point for social security benefits could be before FRA since any starting year of 66 to 70 years of age yields a breakeven age beyond life expectancy. 
Table 3: Cumulative Constant Unit Benefits By Age By Starting Year Assumptions: Inflation Rate = COLA; Discount Rate $=5 \%$

\begin{tabular}{|c|c|c|c|c|c|c|}
\hline Year & Age & FRA & Delay 1 Year & Delay 2 Years & Delay 3 Years & Delay 4 Years \\
\hline 2012 & 66 & 1.0000 & 0.0000 & 0.0000 & 0.0000 & 0.0000 \\
\hline 2013 & 67 & 1.9524 & 1.0314 & 0.0000 & 0.0000 & 0.0000 \\
\hline 2014 & 68 & 2.8594 & 2.0137 & 1.0638 & 0.0000 & 0.0000 \\
\hline 2015 & 69 & 3.7232 & 2.9493 & 2.0770 & 1.0973 & 0.0000 \\
\hline 2016 & 70 & 4.5460 & 3.8403 & 3.0420 & 2.1423 & 1.1318 \\
\hline 2017 & 71 & 5.3295 & 4.6888 & 3.9610 & 3.1376 & 2.2096 \\
\hline 2018 & 72 & 6.0757 & 5.4970 & 4.8362 & 4.0854 & 3.2362 \\
\hline 2019 & 73 & 6.7864 & 6.2666 & 5.6697 & 4.9882 & 4.2138 \\
\hline 2020 & 74 & 7.4632 & 6.9997 & 6.4636 & 5.8479 & 5.1450 \\
\hline 2021 & 75 & 8.1078 & 7.6978 & 7.2196 & 6.6667 & 6.0317 \\
\hline 2022 & 76 & 8.7217 & 8.3626 & 7.9397 & 7.4466 & 6.8763 \\
\hline 2023 & 77 & 9.3064 & 8.9958 & 8.6255 & 8.1892 & 7.6806 \\
\hline 2024 & 78 & 9.8633 & 9.5989 & 9.2786 & 8.8965 & 8.4466 \\
\hline 2025 & 79 & 10.3936 & 10.1732 & 9.9006 & 9.5702 & 9.1762 \\
\hline 2026 & 80 & 10.8986 & 10.7202 & 10.4930 & 10.2117 & 9.8710 \\
\hline 2027 & 81 & 11.3797 & 11.2412 & 11.0571 & 10.8227 & 10.5327 \\
\hline 2028 & 82 & 11.8378 & 11.7373 & 11.5945 & 11.4047 & 11.1629 \\
\hline 2029 & 83 & 12.2741 & 12.2098 & 12.1062 & 11.9589 & 11.7631 \\
\hline 2030 & 84 & 12.6896 & 12.6598 & 12.5935 & 12.4867 & 12.3347 \\
\hline 2031 & 85 & 13.0853 & 13.0884 & 13.0577 & 12.9893 & 12.8791 \\
\hline 2032 & 86 & 13.4622 & 13.4966 & 13.4998 & 13.4681 & 13.3976 \\
\hline 2033 & 87 & 13.8212 & 13.8853 & 13.9208 & 13.9240 & 13.8914 \\
\hline 2034 & 88 & 14.1630 & 14.2555 & 14.3217 & 14.3583 & 14.3616 \\
\hline \multirow[t]{2}{*}{2035} & 90 & 14.4886 & 14.6081 & 14.7036 & 14.7718 & 14.8095 \\
\hline & 91 & 14.7986 & 14.9439 & 15.0672 & 15.1657 & 15.2361 \\
\hline
\end{tabular}

\section{The Impact of Income Taxes on Social Security Benefits Verses Delayed Start of Benefits}

From the above, it is clear that a modest discount rate of 3 percent still encourages delay of benefits for three to four years. However, what about the impacts of income tax on retirement decisions? Many high income retirees reside in high tax states. Is it worthwhile to consider moving at retirement to a new home in a lower tax state?

Before we address the question of taxation effects verses benefit start decision, a short summary of how social security benefits are taxed is in order. First of all, it should be noted that benefits are federal income tax free for the majority of beneficiaries and partially tax free for all beneficiaries. However, the share of benefits taxed can reach up to $85 \%$ for high income beneficiaries. The portion of social security benefits which are taxed depends upon specific thresholds. For example, a single person filing income taxes has thresholds of $\$ 25,000$ and $\$ 32,000$. Whereas, married couples filing a joint return have thresholds of $\$ 32,000$ and $\$ 44,000$. Fifty percent of any excess over the first threshold plus 35 percent of any excess over the second threshold are included in adjusted gross income. For instance, someone with an adjusted gross income of $\$ 67,000$ would have 85 percent of his or her $\$ 20,000$ social security benefit taxed. By the way, income from tax exempt bonds is included in the calculation to determine what portion of social security benefits is taxable.

Estimates of benefits received after income taxes are shown in Table 4 and Table 5. Each table shows constant units of social security benefits subject to 15 percent and 20 percent average tax rates with no discount rates. Fifteen and twenty percent tax rates were selected because there are many married high income retirees who exceed $\$ 68,000$ per year AGI (federal $25 \%$ marginal tax bracket) and whose average tax rate is likely to be in the $15 \%$ and $20 \%$ range. In addition, many retirees live in high tax states, which can add another 5 to 10 percent in marginal tax rates (the top California state income tax rate in 2010 was $9.55 \%$ beginning at $\$ 93,532$ of taxable income for married couples). 
Table 4: Cumulative Constant Unit Benefits By Age By Starting Year

Assumptions: Inflation Rate $=$ COLA; Discount Rate $=0 \%$; Average Tax Rate $=15 \%$

\begin{tabular}{|l|c|c|c|c|c|c|}
\hline Year & Age & FRA & Delay 1 Year & Delay 2 Years & Delay 3 Years & Delay 4 Years \\
\hline 2011 & 66 & 0.8725 & 0.0000 & 0.0000 & 0.0000 & 0.0000 \\
\hline 2012 & 67 & 1.7450 & 0.9449 & 0.0000 & 0.0000 & 0.0000 \\
\hline 2013 & 68 & 2.6175 & 1.8898 & 1.0233 & 0.0000 & 0.0000 \\
\hline 2014 & 69 & 3.4900 & 2.8348 & 2.0467 & 1.1083 & 0.0000 \\
\hline 2015 & 70 & 4.3625 & 3.7797 & 3.0700 & 2.2166 & 1.2003 \\
\hline 2016 & 71 & 5.2350 & 4.7246 & 4.0934 & 3.3248 & 2.4005 \\
\hline 2017 & 72 & 6.1075 & 5.6695 & 5.1167 & 4.4331 & 3.6008 \\
\hline 2018 & 73 & 6.9800 & 6.6144 & 6.1401 & 5.5414 & 4.8011 \\
\hline 2019 & 74 & 7.8525 & 7.5593 & 7.1634 & 6.6497 & 6.0014 \\
\hline 2020 & 75 & 8.7250 & 8.5043 & 8.1868 & 7.7580 & 7.2016 \\
\hline 2021 & 76 & 9.5975 & 9.4492 & 9.2101 & 8.8663 & 8.4019 \\
\hline 2022 & 77 & 10.4700 & 10.3941 & 10.2335 & 9.9745 & 9.6022 \\
\hline 2023 & 78 & 11.3425 & 11.3390 & 11.2568 & 11.0828 & 10.8024 \\
\hline 2024 & 79 & 12.2150 & 12.2839 & 12.2801 & 12.1911 & 12.0027 \\
\hline 2025 & 80 & 13.0875 & 13.2288 & 13.3035 & 13.2994 & 13.2030 \\
\hline 2026 & 81 & 13.9600 & 14.1738 & 14.3268 & 14.4077 & 14.4032 \\
\hline 2027 & 82 & 14.8325 & 15.1187 & 15.3502 & 15.5160 & 15.6035 \\
\hline 2028 & 83 & 15.7050 & 16.0636 & 16.3735 & 16.6242 & 16.8038 \\
\hline 2029 & 84 & 16.5775 & 17.0085 & 17.3969 & 17.7325 & 18.0041 \\
\hline 2030 & 85 & 17.4500 & 17.9534 & 18.4202 & 18.8408 & 19.2043 \\
\hline 2031 & 86 & 18.3225 & 18.8983 & 19.4436 & 19.9491 & 20.4046 \\
\hline 2032 & 87 & 19.1950 & 19.8433 & 20.4669 & 21.0574 & 21.6049 \\
\hline 2033 & 88 & 20.0675 & 20.7882 & 21.4903 & 22.1657 & 22.8051 \\
\hline 2034 & 89 & 20.9400 & 21.7331 & 22.5136 & 23.2739 & 24.0054 \\
\hline 2035 & 90 & 21.8125 & 22.6780 & 23.5369 & 24.3822 & 25.2057 \\
\hline
\end{tabular}

Table 5: Cumulative Constant Unit Benefits By Age By Starting Year

Assumptions: Inflation Rate = COLA; Discount Rate $=0 \%$; Average Tax Rate $=20 \%$

\begin{tabular}{|l|c|c|c|c|c|c|}
\hline Year & Age & FRA & Delay 1 Year & Delay 2 Yearss & Delay 3 Years & Delay 4 Years \\
\hline 2011 & 66 & 0.8300 & 0.0000 & 0.0000 & 0.0000 & 0.0000 \\
\hline 2012 & 67 & 1.6600 & 0.8989 & 0.0000 & 0.0000 & 0.0000 \\
\hline 2013 & 68 & 2.4900 & 1.7978 & 0.9735 & 0.0000 & 0.0000 \\
\hline 2014 & 69 & 3.3200 & 2.6967 & 1.9470 & 1.0543 & 0.0000 \\
\hline 2015 & 70 & 4.1500 & 3.5956 & 2.9205 & 2.1086 & 1.1418 \\
\hline 2016 & 71 & 4.9800 & 4.4944 & 3.8940 & 3.1629 & 2.2836 \\
\hline 2017 & 72 & 5.8100 & 5.3933 & 4.8675 & 4.2172 & 3.4254 \\
\hline 2018 & 73 & 6.6400 & 6.2922 & 5.8410 & 5.2715 & 4.5672 \\
\hline 2019 & 74 & 7.4700 & 7.1911 & 6.8145 & 6.3258 & 5.7090 \\
\hline 2020 & 75 & 8.3000 & 8.0900 & 7.7880 & 7.3801 & 6.8508 \\
\hline 2021 & 76 & 9.1300 & 8.9889 & 8.7615 & 8.4344 & 7.9926 \\
\hline 2022 & 77 & 9.9600 & 9.8878 & 9.7350 & 9.4887 & 9.1344 \\
\hline 2023 & 78 & 10.7900 & 10.7867 & 10.7085 & 10.5430 & 10.2762 \\
\hline 2024 & 79 & 11.6200 & 11.6856 & 11.6820 & 11.5973 & 11.4180 \\
\hline 2025 & 80 & 12.4500 & 12.5845 & 12.6555 & 12.6516 & 12.5599 \\
\hline 2026 & 81 & 13.2800 & 13.4833 & 13.6290 & 13.7059 & 13.7017 \\
\hline 2027 & 82 & 14.1100 & 14.3822 & 14.6025 & 14.7602 & 14.8435 \\
\hline 2028 & 83 & 14.9400 & 15.2811 & 15.5760 & 15.8145 & 15.9853 \\
\hline 2029 & 84 & 15.7700 & 16.1800 & 16.5495 & 16.8688 & 17.1271 \\
\hline 2030 & 85 & 16.6000 & 17.0789 & 17.5230 & 17.9231 & 18.2689 \\
\hline 2031 & 86 & 17.4300 & 17.9778 & 18.4965 & 18.9774 & 19.4107 \\
\hline 2032 & 87 & 18.2600 & 18.8767 & 19.4700 & 20.0317 & 20.5525 \\
\hline 2033 & 88 & 19.0900 & 19.7756 & 20.4435 & 21.0860 & 21.6943 \\
\hline 2034 & 89 & 19.9200 & 20.6745 & 21.4170 & 22.1403 & 22.8361 \\
\hline 2035 & 90 & 20.7500 & 21.5734 & 22.3904 & 23.1946 & 23.9779 \\
\hline
\end{tabular}


There are two aspects to Tables 4 and 5 that are noteworthy. First, the breakeven age is not affected by tax rates. The breakeven ages with $15 \%$ or $20 \%$ tax rates are ages 79 through 82 for delay of 1 year through 4 years respectively. However, the second noteworthy item is the impact of taxation on accumulation of benefits. By 79 years of age, the no tax accumulation with start at FRA is 14.0 units. The accumulation at 79 years of age with a $15 \%$ tax rate is 12.215 units. The accumulation at 79 years of age with a $20 \%$ tax rate is 11.62 . While the reduction in benefits caused by taxes is not surprising, the relative size of the loss of income from an additional 5\% in taxation $(0.595$ units $=12.215-11.62)$ exceeds the maximum benefits gained by delaying start for four years with no tax effect.

For example, in Table 1, the accumulation of unit benefits at 79 years given the choice of delay 4 years has a unit value of 13.7567 compared to the 14.00 units accumulated given the choice of start at FRA. In other words, the decision to delay benefits four years is still a deficit of .2433 units at 79 years of age, while the loss of income from an addition 5\% in income tax is 0.595 units. Assuming a life span of 79 years, the choice of whether to leave or stay in a state with high levels of income tax is more significant for accumulation of benefits than the decision to delay the start of benefits. Also, a delay of benefits by 1 year provides a positive return to 14.07 units. But the 0.07 gain is less than the gain of .595 which arises from moving to a low tax state. Note that the total gain of accumulated benefits between FRA at 20\% tax rate and accumulated benefits at Delay 1 Year at $15 \%$ is 0.6439 units $(=12.2839-11.62)$. These results are summarized in Table 6 below:

Table 6: Accumulated Benefits in Units by Percent Income Tax, by Age of Beneficiary, and by Start Year

\begin{tabular}{|c|c|c|c|c|c|c|c|c|c|}
\hline & $\begin{array}{c}\text { No Income Tax } \\
\text { (Table 1) }\end{array}$ & \multicolumn{5}{|c|}{$\begin{array}{c}\text { Accumulated Benefits in Units With Taxes: } \\
\text { (Table 4-15\% and Table 5-20\%) }\end{array}$} & $\begin{array}{c}\text { Delta: FRA - } \\
\text { Delay Year 1 }\end{array}$ \\
\hline $\begin{array}{c}\text { Age of } \\
\text { Beneficiary }\end{array}$ & FRA & $\begin{array}{c}\text { Delay 1 } \\
\text { Year }\end{array}$ & $\begin{array}{c}\text { Percent } \\
\text { Income Tax }\end{array}$ & FRA & $\begin{array}{c}\text { Delay 1 } \\
\text { Year }\end{array}$ & $\begin{array}{c}\text { Delay 2 } \\
\text { Years }\end{array}$ & $\begin{array}{c}\text { Delay 3 } \\
\text { Years }\end{array}$ & $\begin{array}{c}\text { Delay 4 } \\
\text { Years }\end{array}$ & \\
\hline 79 & 14.00 & 14.07 & 15 & 12.2150 & 12.2839 & 12.2801 & 12.1911 & 12.0027 & 0.0689 \\
\hline 79 & 14.00 & 14.07 & 20 & 11.6200 & 11.6856 & 11.6820 & 11.5973 & 11.4180 & 0.0656 \\
\hline & & & Delta & 0.5950 & 0.5983 & 0.5981 & 0.5938 & 0.5847 & \\
\hline
\end{tabular}

Looking at Table 6 above, which shows the results for 79 years of age, the impact of taxes is shown to cause a greater reduction in benefits than the gain in benefits from delaying start by four years. For example, note that the accumulated benefits between $15 \%$ and $20 \%$ tax rates are between 0.5983 (delay 1 year) to .5938 (Delay 3 years) while the gain from one year delay is only 0.0689 at $15 \%$ and 0.0656 at $20 \%$ tax rate. Even a 4 year delay provides $0.2123(=12.2150-12.0027)$ at $15 \%$ or $0.2020(=11.620-11.418)$ at $20 \%$ compared to starting benefits at FRA. The impact of reducing income taxes 5\% is nearly three times as beneficial as the gains achieved by delaying start of benefits by 4 years.

Similar results are shown in Table 7 below, which compares tax consequences to the delay start decision at 82 years of age. By 82 years of age, the no tax accumulation of benefit with start at FRA is 17.00 and the accumulated benefit at 82 years with a delay of 4 years is 17.8837 , for a difference with no taxes of 0.8837 . Given a delay of 4 years, the accumulation of benefits at 82 years of age with a $15 \%$ tax rate is 15.6035 units. The accumulation at 82 years of age with a $20 \%$ tax rate is 14.8435 . Again, the tax caused reduction in benefits is not surprising, but the relative size of the loss of income from the additional 5\% taxation $(0.760$ units $=15.6035$ $14.8435)$ is only 0.1237 units less than the maximum benefit $(0.8837)$ gained by delaying start for four years with no tax effect. The after tax gain from delaying start by 4 years is 0.7710 at $15 \%$ and 0.7335 at $20 \%$. Clearly, the reduction from taxes is about the same as the gain from delaying start by 4 years.

In other words, the decision to delay benefits four years provides a net benefit of 0.8837 units at age of 82 years (with no tax), while the loss of income from an addition 5\% in income tax is 0.760 units. With a life span of 82 years, the choice of whether to leave or stay in a state with high levels of income tax is nearly as significant for accumulation of benefits as the decision to delay the start of benefits. Finally, note that the total gain in benefits from using both strategies is 1.4935 units $(=15.6035-14.11)$. In other words, a combination of (1) delaying start of benefits and (2) relocating to a lower tax state can add about one and one half years of accumulated benefits by 82 years of age. 
Table 7: Accumulated Benefits in Units by 82 Years of Age, by Percent Income Tax, and by Start Year

\begin{tabular}{|c|c|c|c|c|c|c|c|c|c|}
\hline \multirow[b]{2}{*}{$\begin{array}{c}\text { Age of } \\
\text { Beneficiary }\end{array}$} & \multicolumn{2}{|c|}{$\begin{array}{l}\text { No Income Tax } \\
\text { (Table 1) }\end{array}$} & \multicolumn{6}{|c|}{$\begin{array}{l}\text { Accumulated Benefits in Units With Taxes: } \\
\text { (Table 4-15\% and Table 5-20\%) }\end{array}$} & \multirow[t]{2}{*}{$\begin{array}{l}\text { Delta: FRA- } \\
\text { Delay } 4 \text { Years }\end{array}$} \\
\hline & FRA & $\begin{array}{c}\text { Delay } 4 \\
\text { Years }\end{array}$ & $\begin{array}{c}\text { Percent } \\
\text { Income Tax }\end{array}$ & FRA & $\begin{array}{c}\text { Delay } 1 \\
\text { Year }\end{array}$ & $\begin{array}{c}\text { Delay } 2 \\
\text { Years }\end{array}$ & $\begin{array}{c}\text { Delay } 3 \\
\text { Years }\end{array}$ & $\begin{array}{c}\text { Delay } 4 \\
\text { Years }\end{array}$ & \\
\hline 82 & 17.00 & 17.8837 & 15 & 14.8325 & 15.1187 & 15.3502 & 15.5160 & 15.6035 & 0.7710 \\
\hline 82 & 17.00 & 17.8837 & 20 & 14.1100 & 14.3822 & 14.6025 & 14.7602 & 14.8435 & 0.7335 \\
\hline & & & Delta & 0.7225 & 0.7365 & 0.7477 & 0.7558 & 0.7600 & \\
\hline
\end{tabular}

One can conclude from the above analysis that the best financial strategy for retirees who are likely to reach life expectancy ( 84 years for men who are 66 today), is to delay receipt of social security benefits for four years and move to a lower tax state before the benefits commence.

\section{Discounting to Present Value}

Table 8: Cumulative Constant Unit Benefits By Age By Starting Year

Assumptions: Inflation Rate $=$ COLA; Discount Rate $=3 \%$; Average Tax Rate $=15 \%$

\begin{tabular}{|c|c|c|c|c|c|c|}
\hline Year & Age & FRA & Delay 1 Year & Delay 2 Years & Delay 3 Years & Delay 4 Years \\
\hline 2011 & 66 & 0.8725 & 0.0000 & 0.0000 & 0.0000 & 0.0000 \\
\hline 2012 & 67 & 1.7196 & 0.9174 & 0.0000 & 0.0000 & 0.0000 \\
\hline 2013 & 68 & 2.5420 & 1.8081 & 0.9646 & 0.0000 & 0.0000 \\
\hline 2014 & 69 & 3.3405 & 2.6728 & 1.9011 & 1.0142 & 0.0000 \\
\hline 2015 & 70 & 4.1157 & 3.5124 & 2.8103 & 1.9989 & 1.0664 \\
\hline 2016 & 71 & 4.8683 & 4.3274 & 3.6931 & 2.9549 & 2.1018 \\
\hline 2017 & 72 & 5.5990 & 5.1188 & 4.5501 & 3.8831 & 3.1070 \\
\hline 2018 & 73 & 6.3084 & 5.8871 & 5.3822 & 4.7843 & 4.0829 \\
\hline 2019 & 74 & 6.9972 & 6.6330 & 6.1900 & 5.6591 & 5.0304 \\
\hline 2020 & 75 & 7.6659 & 7.3572 & 6.9743 & 6.5085 & 5.9503 \\
\hline 2021 & 76 & 8.3151 & 8.0603 & 7.7358 & 7.3332 & 6.8435 \\
\hline 2022 & 77 & 8.9454 & 8.7430 & 8.4751 & 8.1339 & 7.7106 \\
\hline 2023 & 78 & 9.5574 & 9.4057 & 9.1928 & 8.9112 & 8.5524 \\
\hline 2024 & 79 & 10.1515 & 10.0492 & 9.8897 & 9.6659 & 9.3697 \\
\hline 2025 & 80 & 10.7283 & 10.6739 & 10.5662 & 10.3986 & 10.1632 \\
\hline 2026 & 81 & 11.2883 & 11.2804 & 11.2231 & 11.1099 & 10.9337 \\
\hline 2027 & 82 & 11.8321 & 11.8692 & 11.8608 & 11.8006 & 11.6816 \\
\hline 2028 & 83 & 12.3599 & 12.4409 & 12.4799 & 12.4711 & 12.4078 \\
\hline 2029 & 84 & 12.8724 & 12.9959 & 13.0811 & 13.1221 & 13.1128 \\
\hline 2030 & 85 & 13.3700 & 13.5348 & 13.6647 & 13.7542 & 13.7973 \\
\hline 2031 & 86 & 13.8531 & 14.0580 & 14.2313 & 14.3678 & 14.4619 \\
\hline 2032 & 87 & 14.3221 & 14.5659 & 14.7814 & 14.9635 & 15.1071 \\
\hline 2033 & 88 & 14.7775 & 15.0591 & 15.3154 & 15.5419 & 15.7335 \\
\hline 2034 & 89 & 15.2195 & 15.5379 & 15.8340 & 16.1035 & 16.3417 \\
\hline 2035 & 90 & 15.6488 & 16.0027 & 16.3374 & 16.6487 & 16.9321 \\
\hline
\end{tabular}

The next part of the analysis is to evaluate the impact of preferring current benefits over future benefits. Given a 3\% discount rate, does it still make financial sense to delay benefits and move to a lower tax state? Tables 8 and 9 show accumulated benefits at a $3 \%$ discount rate for 15\% and 20\% income tax rates. As noted earlier, a $3 \%$ discount rate raises breakeven ages to 82 (Delay 1 Year) and 85 (Delay 4 Years). Also, as mentioned earlier, 85 years of age exceeds the 84 year life expectancy of a man reaching 66 years of age in 2011. Therefore, Tables 10 and 11 below will use 82 and 84 years of age for comparison of delay of start of benefits with relocation to a low tax state. However, it was decided to add Table 12 in order to show the breakeven year of 85 years of age for a delay of benefits by 4 years, although such a delay is a gain only for fortunate healthy long lived men. 
Table 9: Cumulative Constant Unit Benefits By Age By Starting Year

Assumptions: Inflation Rate = COLA; Discount Rate $=3 \%$; Average Tax Rate $=20 \%$

\begin{tabular}{|c|c|c|c|c|c|c|}
\hline Year & Age & FRA & Delay 1 Year & Delay 2 Years & Delay 3 Years & Delay 4 Years \\
\hline 2011 & 66 & 0.8300 & 0.0000 & 0.0000 & 0.0000 & 0.0000 \\
\hline 2012 & 67 & 1.6358 & 0.8727 & 0.0000 & 0.0000 & 0.0000 \\
\hline 2013 & 68 & 2.4182 & 1.7200 & 0.9176 & 0.0000 & 0.0000 \\
\hline 2014 & 69 & 3.1777 & 2.5426 & 1.8085 & 0.9648 & 0.0000 \\
\hline 2015 & 70 & 3.9152 & 3.3413 & 2.6734 & 1.9016 & 1.0145 \\
\hline 2016 & 71 & 4.6312 & 4.1167 & 3.5132 & 2.8110 & 1.9994 \\
\hline 2017 & 72 & 5.3263 & 4.8695 & 4.3285 & 3.6940 & 2.9557 \\
\hline 2018 & 73 & 6.0011 & 5.6003 & 5.1200 & 4.5512 & 3.8840 \\
\hline 2019 & 74 & 6.6563 & 6.3099 & 5.8885 & 5.3835 & 4.7854 \\
\hline 2020 & 75 & 7.2925 & 6.9989 & 6.6346 & 6.1915 & 5.6605 \\
\hline 2021 & 76 & 7.9101 & 7.6677 & 7.3590 & 6.9760 & 6.5101 \\
\hline 2022 & 77 & 8.5097 & 8.3171 & 8.0623 & 7.7377 & 7.3350 \\
\hline 2023 & 78 & 9.0918 & 8.9476 & 8.7451 & 8.4771 & 8.1358 \\
\hline 2024 & 79 & 9.6570 & 9.5597 & 9.4080 & 9.1950 & 8.9133 \\
\hline 2025 & 80 & 10.2057 & 10.1539 & 10.0516 & 9.8921 & 9.6682 \\
\hline 2026 & 81 & 10.7385 & 10.7309 & 10.6764 & 10.5688 & 10.4011 \\
\hline 2027 & 82 & 11.2557 & 11.2910 & 11.2831 & 11.2258 & 11.1126 \\
\hline 2028 & 83 & 11.7579 & 11.8349 & 11.8720 & 11.8636 & 11.8034 \\
\hline 2029 & 84 & 12.2454 & 12.3629 & 12.4439 & 12.4829 & 12.4741 \\
\hline 2030 & 85 & 12.7188 & 12.8755 & 12.9990 & 13.0842 & 13.1253 \\
\hline 2031 & 86 & 13.1783 & 13.3732 & 13.5380 & 13.6679 & 13.7574 \\
\hline 2032 & 87 & 13.6245 & 13.8564 & 14.0613 & 14.2347 & 14.3712 \\
\hline 2033 & 88 & 14.0576 & 14.3255 & 14.5694 & 14.7849 & 14.9671 \\
\hline 2034 & 89 & 14.4782 & 14.7810 & 15.0627 & 15.3191 & 15.5457 \\
\hline 2035 & 90 & 14.8865 & 15.2232 & 15.5416 & 15.8377 & 16.1074 \\
\hline
\end{tabular}

Table 10: Accumulated Benefits in Units by Age 82, by Percent Income Tax, and by Start Year with 3\% Discount Rate

\begin{tabular}{|c|c|c|c|c|c|c|c|c|c|c|}
\hline \multirow[b]{2}{*}{$\begin{array}{c}\text { Age of } \\
\text { Beneficiary }\end{array}$} & \multicolumn{3}{|c|}{$\begin{array}{c}\text { No Income Tax With } 3 \% \\
\text { Discount Rate } \\
\text { (Table 2) }\end{array}$} & \multicolumn{6}{|c|}{$\begin{array}{l}\text { Accumulated Benefits in Units With Taxes and 3\% Discount: } \\
\text { (Table 8-15\% and Table 9-20\%) }\end{array}$} & \multirow[t]{2}{*}{$\begin{array}{c}\text { Delta: } \\
\text { FRA- } \\
\text { Delay } 1 \\
\text { Year }\end{array}$} \\
\hline & FRA & $\begin{array}{c}\text { Delay } 1 \\
\text { Year }\end{array}$ & $\begin{array}{c}\text { Delay } 4 \\
\text { Years }\end{array}$ & $\begin{array}{l}\text { Percent } \\
\text { Income } \\
\text { Tax }\end{array}$ & FRA & $\begin{array}{l}\text { Delay } 1 \\
\text { Year }\end{array}$ & $\begin{array}{l}\text { Delay } 2 \\
\text { Years }\end{array}$ & $\begin{array}{l}\text { Delay } 3 \\
\text { Years }\end{array}$ & $\begin{array}{c}\text { Delay } 4 \\
\text { Years }\end{array}$ & \\
\hline 82 & 13.5611 & 13.6037 & 13.3887 & 15 & 11.8321 & 11.8692 & 11.8608 & 11.8006 & 11.6816 & 0.0371 \\
\hline 82 & 13.5611 & 13.6037 & 13.3887 & 20 & 11.2557 & 11.2910 & 11.2831 & 11.2258 & 11.1126 & 0.0353 \\
\hline & & & & Difference & 0.5764 & 0.5782 & 0.5777 & 0.5748 & 0.7490 & \\
\hline
\end{tabular}

Table 10 above summarizes the results for accumulated benefits by age 82 given an income tax and a 3\% discount rate. Because discounting pushes the breakeven year to older ages, an 82 year old beneficiary receives additional gain by postponing start of benefits for one year only. The "Delta" in the far right column describes the benefit to the beneficiary of postponing benefits one year. Note that the maximum of $0.0371(=11.8692$ 11.8321 )units, which occurs at the $15 \%$ tax rate, is significantly below the difference in accumulated benefits (listed in the bottom row) between low tax $(15 \%)$ and high tax (20\%) states. At the breakeven year for Delay 1 year, the accumulated difference in benefits between low and high tax rates is 0.5782 units, which is substantially higher than 0.0371 units, the gain from a one year in start of benefits. To summarize, in the case where an individual, who expects to live to 82 years of age, has higher preference (3\% discount rate) for current benefits verses benefits in the future, the decision to delay benefits is not as rewarding as the decision to relocate to lower tax states. Note that the total benefit received by the retiree by delaying benefits one year and by relocating to a lower tax state is 0.6135 units (=11.8692-11.2557). Can we expect similar conclusions given discounting of future benefits if the individual expects to live to 84 or 85 years of age? The following tables present results for 84 and 85 years of age. 
Table 11: Accumulated Benefits in Units by Age 84, by Percent Income Tax, by Start Year with 3\% Discount Rate

\begin{tabular}{|c|c|c|c|c|c|c|c|c|c|c|}
\hline \multirow[b]{2}{*}{$\begin{array}{c}\text { Age of } \\
\text { Beneficiary }\end{array}$} & \multicolumn{3}{|c|}{$\begin{array}{c}\text { No Income Tax With } 3 \% \\
\text { Discount Rate } \\
\text { (Table 2) }\end{array}$} & \multicolumn{6}{|c|}{$\begin{array}{l}\text { Accumulated Benefits in Units With Taxes and 3\% Discount: } \\
\text { (Table 8-15\% and Table 9-20\%) }\end{array}$} & \multirow[t]{2}{*}{$\begin{array}{l}\text { Delta: } \\
\text { FRA- } \\
\text { Delay } 3 \\
\text { Years }\end{array}$} \\
\hline & FRA & $\begin{array}{c}\text { Delay } 1 \\
\text { Year }\end{array}$ & $\begin{array}{c}\text { Delay } 4 \\
\text { Years }\end{array}$ & $\begin{array}{l}\text { Percent } \\
\text { Income } \\
\text { Tax }\end{array}$ & FRA & $\begin{array}{l}\text { Delay } 1 \\
\text { Year }\end{array}$ & $\begin{array}{c}\text { Delay } 2 \\
\text { Years }\end{array}$ & $\begin{array}{l}\text { Delay } 3 \\
\text { Years }\end{array}$ & $\begin{array}{l}\text { Delay } 4 \\
\text { Years }\end{array}$ & \\
\hline 84 & 14.7535 & 14.8951 & 15.0290 & 15 & 12.8724 & 12.9959 & 13.0811 & 13.1221 & 13.1128 & 0.2497 \\
\hline 84 & 14.7535 & 14.8951 & 15.0290 & 20 & 12.2454 & 12.3629 & 12.4439 & 12.4829 & 12.4241 & 0.2357 \\
\hline & & & & Delta & 0.6270 & 0.6330 & 0.6372 & 0.6392 & 0.6887 & \\
\hline
\end{tabular}

Table 11 above summarizes the results for accumulated benefits by age 84 given an income tax and a $3 \%$ discount rate. An 84 year old beneficiary can receive additional gain by postponing start of benefits for up to three years. Compared to a one year or two years delay, a delay for three years provides the largest increase in monthly benefits. The "Delta" in the far right column describes the benefit to the beneficiary of postponing benefits for three years. Note that the maximum of $0.2497(=13.1121-12.8724)$ units, which occurs at the $15 \%$ tax rate, is not as large as the difference in accumulated benefits (listed in the bottom row) between low tax (15\%) and high tax (20\%) states.

At the breakeven year for Delay 3 Years, the accumulated difference in benefits between low and high tax rates is 0.6392 units, which is larger than 0.2497 units, the gain from a three year delay in start of benefits. To summarize, in the case where an individual, who expects to live to 84 years of age, and who has higher preference (3\% discount rate) for current benefits verses benefits in the future, the decision to delay benefits is not as rewarding as the decision to relocate to lower tax states. However, by delaying three years and by moving to a lower tax state, the retiree gains a total of 0.8767 units $(=13.1221-12.2454)$.

Table 12: Accumulated Benefits in Units by Percent Income Tax, by Age of Beneficiary, and by Start Year with 3\% Discount Rate

\begin{tabular}{|c|c|c|c|c|c|c|c|c|c|c|}
\hline & \multicolumn{3}{|c|}{$\begin{array}{c}\text { No Income Tax With 3\% } \\
\text { Discount Rate } \\
\text { (Table 2) }\end{array}$} & \multicolumn{3}{|c|}{$\begin{array}{c}\text { Accumulated Benefits in Units With Taxes and 3\% Discount: } \\
\text { (Table 8-15\% and Table 9-20\%) }\end{array}$} & $\begin{array}{c}\text { Delta: } \\
\text { FRA- } \\
\text { Delay 4 } \\
\text { Years }\end{array}$ \\
\hline $\begin{array}{c}\text { Age of } \\
\text { Beneficiary }\end{array}$ & FRA & $\begin{array}{c}\text { Delay 1 } \\
\text { Year }\end{array}$ & $\begin{array}{c}\text { Delay 4 } \\
\text { Years }\end{array}$ & $\begin{array}{c}\text { Percent } \\
\text { Income } \\
\text { Tax }\end{array}$ & FRA & $\begin{array}{c}\text { Delay 1 } \\
\text { Year }\end{array}$ & $\begin{array}{c}\text { Delay 2 } \\
\text { Years }\end{array}$ & $\begin{array}{c}\text { Delay 3 } \\
\text { Years }\end{array}$ & $\begin{array}{c}\text { Delay 4 } \\
\text { Years }\end{array}$ \\
\hline 85 & 15.3238 & 15.5127 & 15.8136 & 15 & 13.3700 & 13.5348 & 13.6647 & 13.7542 & 13.7973 & 0.4273 \\
\hline 85 & 15.3238 & 15.5127 & 15.8136 & 20 & 12.7188 & 12.8755 & 12.9990 & 13.0842 & 13.1253 & 0.4065 \\
\hline & & & & Delta & 0.6512 & 0.6593 & 0.6657 & 0.6700 & 0.6720 & \\
\hline
\end{tabular}

Table 12 above summarizes the results for accumulated benefits by age 85 given an income tax and a $3 \%$ discount rate. An 85 year old beneficiary can receive additional gain by postponing start of benefits for up to four years. Compared to a delay of fewer years, a delay for four years provides the largest increase in monthly benefits permitted by social security. The "Delta" in the far right column describes the benefit to the beneficiary of postponing benefits for four years. Note that the maximum of $0.4273(=13.7973-13.3700)$ units, which occurs at the $15 \%$ tax rate, is not as large as the difference in accumulated benefits (listed in the bottom row) between low tax $(15 \%)$ and high tax $(20 \%)$ states.

At the breakeven year for Delay 4 Years, the accumulated difference in benefits between low and high tax rates is 0.6720 units, which is larger than 0.4273 units, the gain from a four year delay in start of benefits. To summarize, in the case where an individual, who expects to live to 85 years of age, and who has higher preference (3\% discount rate) for current benefits verses benefits in the future, the decision to delay benefits is not as rewarding as the decision to relocate to lower tax states. Furthermore, comparison of the accumulated benefits for FRA at $20 \%$ tax rate relative to the accumulated benefits for Delay 4 Years at $15 \%$ tax rate indicates a total gain of 1.0785 
units (= 13.7973-12.7188). That is, over a full year of benefits can be gained by using both strategies: (1) delay benefits for 4 years and (2) relocate to a lower tax state.

\section{Income Effects on Taxation and Benefits}

In every scenario presented above, the social security beneficiary gains higher levels of accumulated benefits by delaying start of benefits and by relocating to a lower tax state. The analysis presented in this paper has used non denominated units of benefits. By this approach, prospective retirees can simply multiply their scheduled benefits by the number of units and get a dollar amount for each scenario presented in the paper.

As shown in the tables in the preceding paper, the financial benefits from delay of start of benefits and from relocating can be substantial in terms of unit benefits. However, if we begin to use dollar denominated benefits and typical levels of benefits, are the strategies worth the sacrifice to the beneficiaries?

At the present time, the average benefit for retired couples is $\$ 1876$ per month, or $\$ 22,512$ per year. Given this level of average benefit, does it make sense for the average couple to avail themselves of the strategies of delaying social security benefits and moving to lower tax states?

From Table 1, delaying benefits for four years can add 0.8837 units to accumulated benefits by age 82 . In dollar values, the average couple gains $\$ 19,894$ by delaying benefits 4 years. Their annual benefit would increase $38 \%\left(1.00667^{\wedge} 48=1.3759\right)$ to $\$ 30,969$. If social security is $100 \%$ of their income, they will pay no federal taxes on their $\$ 30,969$ annual social security benefits since they are below the $\$ 32,000$ threshold. In California, their tax bracket would be $2.25 \%(\$ 14,248$ to $\$ 33,780)$. Depending upon their deductions and other factors in their California return, they would probably pay less than $\$ 500$. At these income levels, there is much less tax incentive to relocate to a lower tax state. Could they wait four years before starting social security? It would depend upon a number of factors such as savings, personal health, availability of work, and social net work considerations.

What about individuals who are making the maximum benefit of $\$ 2,323$ per month, or $\$ 27,876$ per year? Given the threshold level of $\$ 25,000$ per year for individuals, a beneficiary making $\$ 27,876$ per year might find that about $50 \%$ of $\$ 2,876(=\$ 27,896-\$ 25,000)$ could be taxed. The federal tax rate would likely by $10 \%$ with a resultant income tax of about $\$ 288$. If the individual has no significant other income, there is little incentive to relocate. The decision to delay benefits would depend on a number of factors as noted earlier.

The individuals and couples who might benefit from the strategies described in this paper would most likely be high income couples or individuals. For example, a retiree from a California public employer with a guaranteed pension of $\$ 80,000$ per year and who is eligible for $\$ 2,300$ per month ( $\$ 27,600$ per year) in social security benefits at FRA, would likely benefit from delaying the start in benefits and from moving to a lower tax state. At these income levels, $85 \%$ of all social security benefits are subject to federal income tax and some benefits could be subject to the maximum rate of California income tax. By delaying start of benefits for 4 years (and assuming a 3\% COLA), the $\$ 2,300$ per month benefit increases to about $\$ 3,561$ per month or about $\$ 42,734$ per year. Clearly, the former public employee would have eventually an adjusted gross income in excess of $\$ 100,000$ and face marginal tax rate levels of about $34 \%$ in California ( $=25 \%$ Federal and $9.55 \%$ State). A quick relocation to Nevada, which has no income tax, could conservatively save the individual about $\$ 6,000$ or $\$ 7,000$ per year. Just think, the state of California will indirectly provide high income retirees a bonus of about $\$ 6,000$ or $\$ 7,000$ per year to move out of state.

\section{SUMMARY}

The results of the previous analysis and tables are summarized in Table 13 below. Note that the breakeven ages change by year of delay of start because of discount rate, not tax rates. The different average rates of income tax $(0 \%, 15 \%$, and $20 \%)$ do not alter the breakeven age. The breakeven age is not effected since tax rates are assumed to remain the same throughout the remaining life of the beneficiary. The assumption of constant rates makes the calculations much simpler and seems reasonable given that most beneficiaries are not at income levels targeted for increased taxation in the current tax and deficit debates. 
Table 13: Summary of Breakeven Age by Start Year, Discount Rate and Tax Rate

\begin{tabular}{|l|c|c|c|c|c|c|}
\hline & Delay 1 Year & Delay 2 Years & Delay 3 Years & Delay 4 Years & Discount Rate & Tax Rate \\
\hline $\begin{array}{l}\text { Breakeven } \\
\begin{array}{l}\text { Ages by Years } \\
\text { of Delay in }\end{array}\end{array}$ & 89 & 81 & 82 & $0 \%$ & $\begin{array}{c}\text { No Income Tax, } \\
15 \% \text { and } 20 \%\end{array}$ \\
\cline { 2 - 7 } $\begin{array}{l}\text { Start of } \\
\text { Benefits }\end{array}$ & 82 & 83 & 84 & 85 & $3 \%$ & $\begin{array}{c}\text { No Income Tax, } \\
15 \% \text { and } 20 \%\end{array}$ \\
\cline { 2 - 8 } & 85 & 86 & 87 & 88 & $5 \%$ & No Income Tax \\
\hline
\end{tabular}

At discount rates less than of $3 \%$ or less, the accumulated benefits may be increased by delay of start for up to 3 years since breakeven age occurs within the expected life span, favoring the choice to delay start of social security benefits. At a 3\% discount rate, a delay of 4 years results in a breakeven age of 85 years--one year beyond the expected lifespan of a man turning 66 in 2011. If no discount rate is applied, accumulated benefits are maximized by delayed start since all breakeven ages occur within life expectancy.

However, as noted earlier, maximizing present value may not be the most important consideration in the retirement decision. Many retirees choose to delay benefits even though the choice to delay has a lower present value of accumulated benefits. Many retirees express great fear of inflation and a recent Allianz poll (2010) found that $61 \%$ of individuals would rather die that run out of money. Delaying the start of social security benefits until 70 can significantly increase monthly benefits, particularly if the individual continues to work. The monthly increase could be viewed as a "hedge" to reduce the impact of expected inflation. Consequently, while our financial analysis with discounting suggests taking benefits at FRA or with only a short delay, a strong preference to have adequate flow of funds in an uncertain future seems to "trump" a higher present value today. Such preferences indicate that some retirees do not have "high" discount rates for future earnings, but evaluate benefits in terms of current cash flow where higher is greatly preferred over lower.

Finally, as shown in Tables 10 through 12, the negative impact of taxes on accumulated benefits can be as large as a low discount rate of $3 \%$ on accumulated benefits. For high income retirees, a strategy of (1) relocating to lower tax states and (2) delaying the start of benefits can provide substantial increases to accumulated benefits.

In summary, there are substantial incentives to delay the start of social security benefits and to relocate to lower tax states. The incentives tend to apply most to high income individuals and couples, who face high marginal tax rates and are likely to have substantial portions of their social security benefits subject to federal tax. The incentives are not as attractive to lower income individuals for whom social security benefits are not taxed and who are less likely to have the resources to delay the start of social security.

\section{ACKNOWLEDGEMENT}

The research assistance of Jennifer Hebein in the development of this article is greatly appreciated. Ms. Hebein is a senior majoring in economics at Pomona College in Claremont, California.

\section{AUTHOR INFORMATION}

Professor Hebein has had a rewarding career in academe and industry. During his tenure with CSUSB, Dr. Hebein has received numerous awards for Teaching Excellence, Research and Publication, and Professional Service. In his business career, Dr. Hebein served as VP of Marketing and as Director of Business Development for several companies. In those capacities, he developed profitable marketing programs and directed product development programs to successful commercialization and patent acknowledgement. Dr. Hebein received his Ph. D. from Southern Methodist University and his Profession Degree in Engineering from the Colorado School of Mines. E-Mail: fhebein@csusb.edu

\section{BIBLIOGRAPHY}

1. Burtless, Gary. 1986. "Social Security, Unanticipated Benefit Increases, and the Timing of Retirement," The Review of Economic Studies, vol. 53, no. 5, October, pp. 781-805. 
2. Clements, Donna A. 2009. Guide to Social Security ( $37^{\text {th }}$ ed).

3. Crawford, Vincent P., and David M. Lilien. 1981. "Social Security and the Retirement Decision," The Quarterly Journal of Economics, vol. 96, no. 3, August, pp. 505-529.

4. Duggar, James E., and Robert Gillingham. 1999. "The Effect of Errors in the CPI on Social Security Finances," Journal of Business \&Economic Statistics, vol. 17, no. 2, April, pp. 161-169.

5. Fahlund, Christine. 2011. "Delaying Retirement, But Not Your Retirement Dreams," American Association of Individual Investors, vol. 33, no. 7, July, pp. 13, 14, 17.

6. $\quad$ Fahlund, Christine. 2009. "Retirement Income: Repairing the Damage to Assure the Flow," American Association of Individual Investors, vol. 31, no. 2, February, pp. 5-9.

7. Fisher, T. Lynn. 2007. "Measuring the Relative Importance of Social Security Benefits to the Elderly," Social Security Bulletin, vol. 67, no. 2, pp. 65-72.

8. Henkens, Kène, and Hanna van Solinge. 2002. "Spousal Influences on the Decision to Retire," International Journal of Sociology, vol. 32, no. 2, Summer, pp. 55-74.

9. Hobijn, Bart, and David Lagakos. 2003. "Social Security and the Consumer Price Index for the Elderly," Federal Reserve Bank of New York, vol. 9, no. 5, May, pp. 1-6.

10. Hogan, Paula H. 2011. "The Role of Inflation-Indexed Annuities," American Association of Individual Investors, vol. 33, no.3, March, pp. 29-32.

11. Johnson, Richard. 2002. "The Puzzle of Later Male Retirement," Federal Reserve Bank of Kansas City Economic Review, Third Quarter, pp. 5-24.

12. Muksian, Robert. 2011. "Social Security: Delay or Take the Money and Run - Act II," American Association of Individual Investors, vol. 33, no. 5, May, pp. 13-16.

13. News Release. 2010. "Outliving Your Money Feared More Than Death," Allianz Life Insurance Company of North America, June 17.

14. O'Rand, Angela M., and Janice, Parkas. 2002. "Couples' Retirement Timing in the United States in the 1990s.” International Journal of Sociology," vol. 32, no. 2, Summer, pp. 11, 19.

15. Reichenstein, William. 2008. "Will Your Savings Last? What the Withdrawal Rate Studies Show," American Association of Individual Investors, vol. 30, no. 6, July, pp. 5-11.

16. Spiegelman, Rande. "When Should You Take Social Security?” Schwab Center for Financial Research, February 4, 2011, pp. 1-8.

17. Turner, John A. 2010. "Rating Retirement Advice: A Critical Assessment of Retirement Planning Software," Benefits Quarterly, Fourth Quarter, pp. 40-49. 